\title{
The Weight of Eye Lens as the Proposed Age Indicator of the Bank Vole
}

Ciężar soczewki jako proponowany wskaźnik wieku nornicy rudej

\section{Michał KOZAKIEWICZ}

\begin{abstract}
Kozakiewicz M.: The weight of eye lens as the proposed age indicator of the bank vole. Acta theriol., 21, 23: $314-316$. [With 2 Figs.]

Statistical significance was found between age and eye lens weight in 40 individuals of the bank vole, Clethrionomys glareolus ( $\mathrm{S} \mathrm{ch} \mathrm{r} \mathrm{e-}$ be $r, 1780$ ). It is suggested that eye lens weight may be used as the index of age of voles during first three months of life, while in older animals this index can be used simultaneously with the measurement of $M_{1}$ teeth roots length.
\end{abstract}

[Dept. Zool. Ecol., Warsaw Univ., Krakowskie Przedmieście 26/28, 00-927 Warszawa].

The principal method used hitherto in age estimation of the bank vole, Clethrionomys glareolus ( $\mathrm{S} \mathrm{chr}$ e be $\mathrm{r}, 1780$ ) depends on measurement of the root length in molar teeth $M_{1}(\mathrm{Pucek}$, \& $\mathrm{Zejda}, 1968)$ or $M_{2}$ (Tupikova, Sidorova, \& Konovalova, 1968). This method, although very accurate, can be applied only to the individuals older than 3 months, since the roots of molar teeth begin to form during third month of life of bank vole (W a silew ski, 1952; M a zák, 1963; H a it 1 in g e r, 1965; P u c e k \& Z e jd a, 1968; L ow e, 1971, and others). The age of bank voles during first 3 months of life can be estimated from water content in the organism ( $\mathrm{F} \mathrm{e} \mathrm{d} \mathrm{y} \mathrm{k,} \mathrm{1974).} \mathrm{The} \mathrm{latter} \mathrm{method,} \mathrm{how-}$ ever, is not convenient because during drying of the carcass all the internal organs are destroyed and several analyses cannot be carried out. In such situation it was reasonable to find out a new age index for the bank vole; the weight of the eye lenses was utilized for such purpose in several other mammals (L o r d, 1959; D u d z iński \& M y k y t ow ic z, 1961; A d a m c z e w s ka-A nd r zejew s ka, 1973, and others).

The material analysed in the present study consisted of 40 individuals of the bank vole trapped in the years 1973 and 1974 in the isolated island population investigated by means of live traps in two-week series of trappings repeated several times during the year. The fate of each individual in the population was followed with the method of calendar of catches. The captured individuals belonged to various generations: spring generation (born in April and May) - 5 individuals, summer generation (born in June and July) - 25 individuals, and autumn generation (born in September) - 10 individuals. The age of animals was estimated from the date of the first and last trappings. Body weight of each analysed animal did not exceeded $11 \mathrm{~g}$ at the moment of the first trapping, hence it was assumed that this trapping occurred around 26th day of life (M a z urkiewicz, 1972). The eye lenses of examined animals were fixed in $10 \%$ formaldehyde solution, dried to constant weight and weighed with the accuracy of $0.1 \mathrm{mg}$ as described by L or d (1959). The length of molar teeth roots $M_{1}$ was measured according to the method of P u c e k \& Z e j d a (1968). The analysis was applied to the relationship between the total weight of lenses from two eyes and age of voles up to 3 months and after 3 months, as well as between $M_{1}$ molar root length 
and age of animals. For these relationships the correlation coefficients $r$ were calculated and after ascertaining their significance (at $P=0.05$ ) the relationships were estimated from the equation of linear regression $(y=$ $=a x+b)$.

Analysis of 23 individuals in the age under 3 months showed a very high correlation coefficient between the age of animals and eye lens weight $(r=0.922)$, statistically significant at $P=0.05$. When analysing the same relationship for 17 individuals older than 3 months the correlation coefficient was 0.906 , also statistically significant at $P=0.05$. The

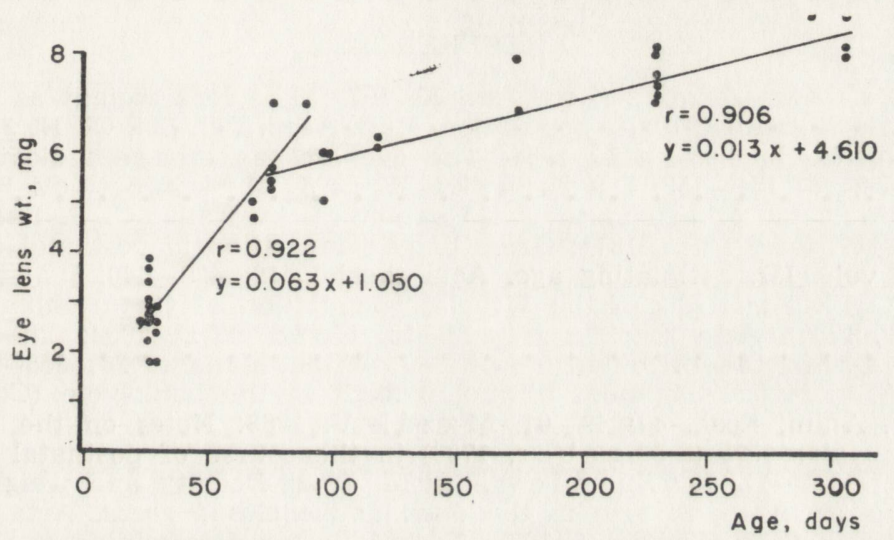

Fig. 1. Relationship between eye lens weight and age of the bank vole.

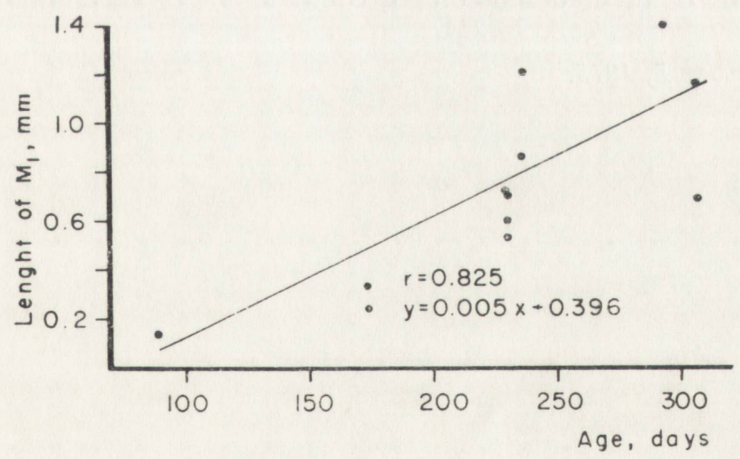

Fig. 2. Relationship between the length of $M_{1}$ roots and age of the bank vole.

rate of increase of eye lens weight during first 3 months of life of the bank vole is considerably higher than in older individuals (Fig. 1). Statistical significance was also observed at $P=0.05$ for the correlation coefficient $(r=0.825)$ between age and length of $M_{1}$ molar teeth roots in analysed 13 voles (Fig. 2).

The obtained results indicate that during the life of bank vole the rate of increase of eye lens weight is slowing down with age, in agre- 
ement with the observations of Askaner \& Hans on (1967). The highest rate of increase of eye lens weight during first three months of life, as well as a high correlation coefficient between age and eye lens weight in this period, suggest that the weight of eye lenses is a very good indicator of age of voles without developed teeth roots. It can be supposed that interchangeable application of both indices may considerably improve the age estimation of the bank vole, especially in young individuals. In the individuals older than 3 months the accuracy of age estimation should be increased by simultaneous application of both indices, since each of them is well correlated with age.

\section{REFERENCES}

A d a mczewska-Andrzejewska K. 1973: The lens weight as indicator of age in the wild Microtus arvalis population. Bull. Acad. Pol. Sci. Cl. II, 21: 331-336. Askaner T. \& Hansson L. 1968: The eye lens as an age indicator in small rodents. Oikos, 18: 151-153. Dudziński M. L. \& M y k t owicz R. 1961: The eye lens as indicator of age in the wild rabbit of Australia. C. S. I. R. O. Wildl. Res., 6: 156-159. Fe d y k A. 1974: Gross body composition in postnatal development of the bank vole. III. Estimating age. Acta theriol., 19: 429-440. H a i t ling e r R. 1965: Morphological analysis of the Wrocław population of Clethrionomys glareolus (S chreber, 1780). Acta theriol., 10: 18-26. Lord R. D. 1959: The lens as an indicator of age in the cottontail rabbits. J. Wildl. Manage, 23: 358-360. Low e V. P. W. 1971: Root development of molar teeth in the bank-vole (Clethrionomys glareolus). J. Anim. Ecol., 40: 49-61. M a z á k V. 1963: Notes on the dentition in Clethrionomys glareolus (Schreber, 1780) in the course of postnatal life. Säugetierkdl. Mitt., 1: 1-11. M a z urkiewicz M. 1972: Density and weight structure of populations of the bank vole in the open and enclosed areas. Acta theriol., 17: 455-465. P u cek Z. \& Z e j da J. 1968: Technique for determining age in the red-backed vole, Clethrionomys glareolus (S c h r e b e r, 1780). Small Mammal Newslett., 2: $51-60$. Tupikova N. V., Sidorova G. A. \& Konovalova E. A. 1968: A method of age determination in Clethrionomys. Acta theriol., 13: 99-115. W a s ile wski W. 1952: Badania nad morfologią Clethrionomys glareolus $\mathrm{S} \mathrm{ch} \mathrm{re} \mathrm{b.} \mathrm{Annls}$ Univ.M. Curie-Skłodowska, 7: 119-214.

Accepted, December 5, 1975. 